\title{
Tectonic evolution and uplift of the Qinghai-Tibet Plateau
}

Based on a paper presented at the 10th Himalaya-Karakoram-Tibet Workshop, Ascona, Switzerland, 1995

Recent studies on palaeobiogeography, sedimentography and palaeomagnetism, show that terranes comprising the Qinghai-Tibet plateau and accreting to Eurasia during the late Palaeozoic-Mesozoic, did not drift northward across a vast ocean. At that time there was only an epeiric sea, or a limited ocean basin, rather than a vast eastward-opening Tethys. Uplift rates of the plateau have been deduced and a mechanism for the formation of the plateau is described.

\section{Tectonic evolution}

The tectonic evolution of the Qinghai-Tibet plateau (QTP) is related to the splitting of Gondwana land and to the evolution of Tethys. It is one of the highest plateaus in the world, an active earthquake zone, a strongly uplifted mountain region and a place of unique morphogenesis making it an area of considerable interest and the subject of lively discussion among geoscientists worldwide.

The tectonic units of the Qinghai-Tibet plateau and the suture zones between them are shown in Figure 1.

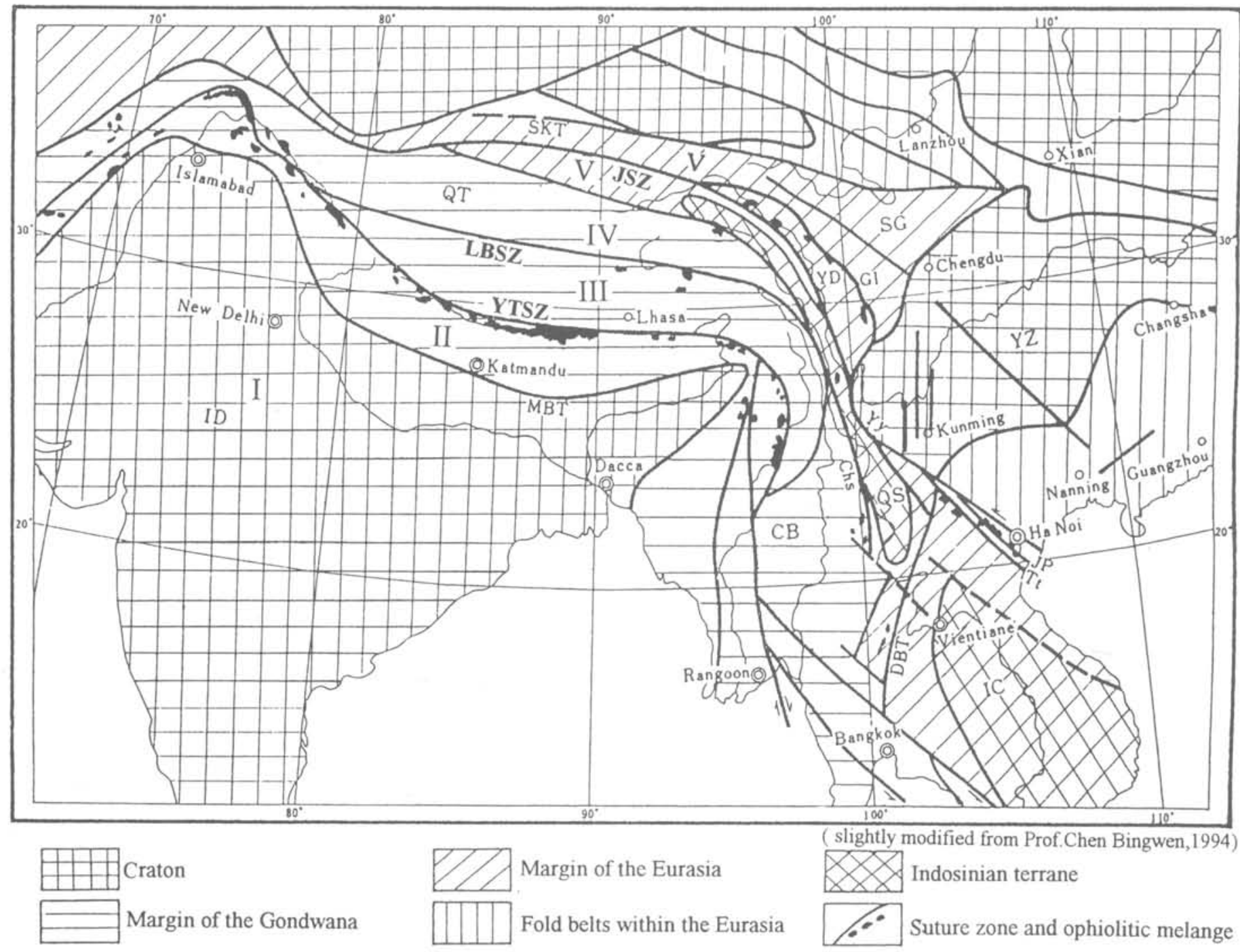

Figure 1 Tectonic divisions of the Qinghai-Tibet plateau and adjacent areas. I Indian craton (terrane); II Himalaya terrane; III Gangdise ( or Lhasa) terrane; IV Qiangtang terrane; V Hohxil-Baryan Har terrane; MBT main boundary fault zone; YTSZ Yarlung-Tsangpo suture zone; LBSZ Lancang-Bangong suture zone JSZ Jinshajiang suture zone. 
Table 1 Tertiary palaeomagnetism and crustal shortening of the Qinghai-Tibet plateau.

\begin{tabular}{|c|c|c|c|c|c|c|c|}
\hline Terrane & Age & $\begin{array}{l}\text { Palaeolatitude } \\
\left(\mathrm{D}^{\circ}\right)\end{array}$ & $\begin{array}{l}\text { Modern } \\
\text { latitude } \\
\left(\mathrm{D}_{1}^{\circ}\right)\end{array}$ & $\begin{array}{l}\text { Northward } \\
\text { displacement } \\
\& \text { latitude } \\
\left(D_{1}^{\circ}-D^{\circ}\right) \times 110\end{array}$ & $\begin{array}{l}\text { Distance } \\
\text { between } \\
\text { terranes }\end{array}$ & $\begin{array}{l}\text { Shortening } \\
\text { of crust }(\mathrm{km})\end{array}$ & $\begin{array}{l}\text { Source } \\
\text { of data }\end{array}$ \\
\hline Himalaya & Tertiary & $\begin{array}{l}4.5^{\circ} \mathrm{N} \\
\left(2.5^{\circ}-5^{\circ} \cdot 4.6^{\circ} \mathrm{N}\right)\end{array}$ & $28.5^{\circ} \mathrm{N}$ & $\begin{array}{l}24^{\circ} \\
2664 \mathrm{~km}\end{array}$ & & & A \\
\hline Gangdise & Tertiary & $\begin{array}{l}12^{\circ} \mathrm{N} \\
(10-13.8)\end{array}$ & $30^{\circ} \mathrm{N}$ & $\begin{array}{l}18^{\circ} \\
1980 \mathrm{~km}\end{array}$ & $130 \mathrm{~km}$ & $2664-(1980+130)=554$ & B \\
\hline Qiangtang & Tertiary & $\begin{array}{l}27.5^{\circ} \mathrm{N} \\
(25.4-29.5)\end{array}$ & $32.5^{\circ} \mathrm{N}$ & $\begin{array}{l}5^{\circ} \\
550 \mathrm{~km}\end{array}$ & $440 \mathrm{~km}$ & $1980-(550+440)=990$ & $\mathrm{C}$ \\
\hline Qaidam & Tertiary & $\begin{array}{l}37^{\circ} \mathrm{N} \\
\left(34^{\circ}-40^{\circ}\right)\end{array}$ & $38^{\circ} \mathrm{N}+$ & $\begin{array}{l}1^{\circ} \\
110 \mathrm{~km}\end{array}$ & $480 \mathrm{~km}$ & $550-(110+480)=-40$ & $\mathrm{D}$ \\
\hline
\end{tabular}

A Sino-French joint investigation in Himalaya region, 1984, Dong Xuebing et al., 1990.

B Michele Westphal, Zhou Yaoxin et al., 1983, Dong Xucbing, 1990.
C Zhou Yaoxin, Courtillot, et al., 1984, Dong Xuebing, 1990.
D Dong Xucbing, 1992, Li Yongan, 1992 .
Since the emergence of plate tectonic theory in the late 1960s, many geoscientists have believed that the Indian terrane, the Himalaya terrane and the southern terranes of the Qinghai--Tibet plateau successively accreted to Eurasia, after being separated from northern Gondwana land, and drifting northward across a vast deep ocean $7000-8000 \mathrm{~km}$ wide, the so-called palaeo-Tethys, around 200 Ma ago (Dietz and Holden, 1970).

Recent studies on palacobiogeography, sedimentary facies and palaeomagnetism indicate that during the late Palaeozoic-early Mesozoic (Triassic), most of Tethys was an epeiric sea instead of a vast deep ocean, except perhaps for belts along the Jinshajiang River and the South Kunlun Mountains. These might have been rifted to form a narrow deep trough or a small ocean basin represented by minor and dismembered ophiolite. A quantitative palaeobiogeographical analysis of the Carboniferous-Triassic fauna and flora of Qinghai-Tibet has been presented by Smith et al. (1990). It indicates that there was no suture line consistently marking the position of a faunal or floral break during the late Palaeozoic-late Triassic and there appears to have been no physical barrier, such as a vast ocean, to biotic dispersal between terranes of the Qinghai-Tibet plateau at that time. A palaeomagnetic study also indicates that in the late Palaeozoic, there was no $7000 \mathrm{~km}$-wide ocean between Eurasia and Gondwana from which a number of blocks became detached, including south China, Indochina, Afghanistan, Iran, Kunlun, Qiangtang and Karakoram etc., and accreted to form the Cathaysian composite continent (Lin Jinlu et al., 1990).

Tetrapod fossil evidence (Chatterjee, 1987; Sun Ailing et al., 1992) shows that all of the Indian Tetrapod families are present in the northern region including China, East Asia, Africa, Europe and particularly North America but are absent in Australia and Antarctica. So it is believed that the India plate and Asia remained an integral geographic unit during the late Triassic and even early Jurassic. In the Jurassic to early Cretaceous period, although the YarlungTsangpo suture zone seems to be the result of the closing of an ocean basin, the palaeobiocoenosis, palaeogeography and sedimentary facies both to the north and south of the Yarlung-Tsangpo suture zone were characterized by an epibenthic environment (Xia Daixiang et al., 1993). Therefore, the ophiolite occurring along the Yarlung-Tsangpo suture zone probably represents relics of oceanic crust-upper mantle rocks of a limited (small) ocean basin or a narrow deep trough of Jurassic to early Cretaceous age.

The REE, bulk composition, stable elements and isotope contents of ophiolites can be used to deduce (even if indirectly) the spreading rate parameters. Such data from the Yarlung-Tsangpo ophiolite suggest a slow spreading rate (less than $2 \mathrm{~cm} / \mathrm{a}$, averaging about $1.5 \mathrm{~cm} / \mathrm{a}$ ) (Mo Xuanxuc, 1992; Xiao Xuchang, in press). The duration of the ocean basin represented by the Yarlung Tsangpo ophiolite is from about 190 Ma (Jurassic) to 100 Ma (early Cretaceous). The width of the basin is roughly cstimated at $2700 \mathrm{~km}$ $[(190-100) \mathrm{Ma} \times 1.5 \mathrm{~cm} / \mathrm{a}) \times 2]$.

All of the above evidence indicates that the Indian terrane lay near the Gangdise (Lhasa) terrane and did not drift far to the south. From the Jurassic to the Cretaceous, most of the area between the Indian terrane and the QTP was covered by an epeiric sea. The Yarlung-Tsangpo suture zone resulted only from the subduction and consumption of a limited (small) ocean basin. During that time, Antarctica and Australia split from India, and drifted to the south.

It is appropriate to recall the words of Alfred Wegener (1924), written 60 years ago, on the evolution of the Himalayas and Tibetan high land:

The case of India is somewhat different: it was originally connected by a long continental tract, mostly, it is sure, covered by shatlow sea, to the Asiatic continent... this long connecting portion was more and more folded together through the continuous gradual approach of India to Asia and constitutes today the mightiest mountain folds of the earth, the Himalayas and the numerous folded ranges of the highlands of Asia.

\section{Crustal thickening, shortening and uplift}

From studies of palaeomagnetism, sedimentology, tectonic history, stratigraphic palaeontology, magmatism, high-pressure and lowtemperature metamorphic belts and ophiolite, the unanimous view is that the neo-Tethys ocean basin closed at the end of the Cretaceous-Eocene, and the Indian terrane collided with Eurasia; since then (about 65-50 Ma ago), there has been crustal thickening, shortening and uplift in the QTP.

Until now, estimates of the rate of northward movement and displacement of the Indian terrane since the Tertiary have not been generally accepted, but some idea of the rate is possible after preliminary analysis. The main conclusions of this analysis are:

- The northward drift rates of the Indian terrane after its convergence with Eurasia in Eocene epoch was $16-17 \mathrm{~cm} / \mathrm{a}$ at $65-50$ $\mathrm{Ma}$; about $10 \mathrm{~cm} / \mathrm{a}$ in the Oligocene-Miocene, and $2-10 \mathrm{~cm} / \mathrm{a}$ in the late Pliocene (Dong Xuebin et al., 1990; Klootwijk et al., 1992; Molnar et al., 1987; Patriat et al., 1984; Zhou Yaoxin et al., 1990). The accepted rate of the northward compression from the Indian terrane since the Pliocene is 50-60 $\mathrm{mm} / \mathrm{a}$, of which $5 \mathrm{~mm} / \mathrm{a}$ is absorbed by compressive faults or thrusts in the Himalaya terrane; $15 \mathrm{~mm} / \mathrm{a}$ by the strike-slip faults in the Gangdise terrane; $12 \mathrm{~mm} / \mathrm{a}$ by the strike-slip faults in the Qiangtang terrane; $8 \mathrm{~mm} / \mathrm{a}$ by the strike-slip faults 
Table 2 Tertiary uplift rates of the Qinghai-Tibet plateau.

\begin{tabular}{|c|c|c|c|c|c|}
\hline Method & $\begin{array}{l}\text { Region } \\
\text { (from } S \text { to } N)\end{array}$ & Uplift age & $\begin{array}{l}\text { Uplift rate } \\
(\mathbf{m m} / \mathbf{a})\end{array}$ & $\begin{array}{l}\text { Denudation } \\
\text { rate }(\mathbf{m m} / \mathbf{a})\end{array}$ & Source of data \\
\hline $\begin{array}{l}\text { Geodetic levelling } \\
\text { GPS + SLR }\end{array}$ & $\begin{array}{l}1 \text { Qomolangma (Everest) } \\
2 \text { Himalaya } \\
3 \text { Lhasa-Gangdise } \\
4 \text { Kunlun-Karakoram }\end{array}$ & $\begin{array}{l}\text { last } 30 \text { years } \\
0.01 \mathrm{Ma} \text {-last few years } \\
0.01 \mathrm{Ma} \text {-last few years } \\
\text { last } 30 \text { years }\end{array}$ & $\begin{array}{l}37 \\
10-15 \\
9-10 \\
6-9\end{array}$ & & $\begin{array}{l}\text { J Y Chen et al. } \\
\text { (National Bureau } \\
\text { of Surveying and } \\
\text { Mapping, China, 1994) }\end{array}$ \\
\hline \multirow[t]{2}{*}{ Fission track } & Western Himalaya & $\begin{array}{l}5-1 \mathrm{Ma} \\
20-10 \mathrm{Ma} \\
40-30 \mathrm{Ma}\end{array}$ & $\begin{array}{l}0.2-0.9 \\
0.92 \\
0.1-0.3\end{array}$ & $\begin{array}{l}5(?) \\
0.08-0.22\end{array}$ & $\begin{array}{l}\text { P K Zeitter et al., } 1985,1991 \\
\text { P F Cerveny et al., } 1988\end{array}$ \\
\hline & Lhasa-Gangdise & $12-8 \mathrm{Ma}$ & $\begin{array}{l}0.45-0.5 \\
0.25\end{array}$ & & $\begin{array}{l}\text { Liu Shunsheng et al. } \\
\text { (Institute of Geology } \\
\text { Academica Sinica) }\end{array}$ \\
\hline $\begin{array}{l}\text { Study of dislocition } \\
\text { geomorphology }\end{array}$ & Karakoram & $0.01 \mathrm{Ma}-$ last few years & $4-5$ & & $\begin{array}{l}\text { Liu Qing (Doctoral thesis } \\
7 \text { th University of Paris, 1993) }\end{array}$ \\
\hline
\end{tabular}

and the Red River right lateral strike-slip fault in the Yunnan block; about $11 \mathrm{~mm} / \mathrm{a}$ by the Altun, Kunlun and Qilian fault systems, and about $3-5 \mathrm{~mm} / \mathrm{a}$ by the Tianshan fault system.

- From the Himalaya terrane to Qaidam terrane, the displacement successively decreases, i.e. from $2664 \mathrm{~km}$ to $110 \mathrm{~km}$ (Table 1).

- It is noteworthy that, based on the movement distance of the above terranes, the crust shortening (or compression) from the Gangdise terrane to Qiangtang terrane can be roughly calculated, at $990 \mathrm{~km}$. This is more than the shortening between the Himalaya and Gandise terranes or that between the Qiantang and Qaidam terranes. These data are consistent with those of the geophysical survey, i.e., the Gangdise terrane and the area north of it have a 'thick crust', also indicating that the Qaidam terrane in the north of the QPT was an obstruction to the compressive force from the south.

The rapid uplift of the QTP since the late Tertiary is fully demonstrated by data on neotectonics, geomorphology, palaeontology and sedimentology (Li Tingdong. 1988; Pan Guitang et al., 1990; Zhang Qingrong et al., 1992). The uplift rates of the QTP, obcained using various methods in the last few years, are generalized in Table 2. The rate of uplift has increased with time: $0.1 \sim 0.4 \mathrm{~mm} / \mathrm{a}$ in the Eocene to Miocene, $0.4 \sim 0.5 \mathrm{~mm} / \mathrm{a}$ in the Pliocene to Pleistocene. and $4 \sim 15 \mathrm{~mm} / \mathrm{a}$ in the Plejstocene to Holocene. Since the Holocene, the uplift rate has increased rapidly from north to south (Fïgure 2).

The uplift process of the QTP can be divided into three major stages:

- A slow uplift stage in the late Cretaceous-Eocene, which mainly resulted from the collision between the Indian terrane and the southern terrane of the QTP as well as the subduction of the former bencath the latter.

- A medium uplift stage in the Oligocene-Pliocene, which mainly resuited from the compressive deformation within the amalgamated terranes.

- A rapid uplift stage in the Holocene, which mainly resulted from the isostatic adjustment.

Concerning the uplift model and mechanism, there have beenlively discussions during the last 20 years. (Dewey, Shackleton, Chang Chenfa and Sun Yiyin, 1990; Harrison et al., 1992, Li Tingdong, 1988: Meng Lingshun, 1992; Molnar et al., 1987a; Patriat et al., 1984; Pan Guitang et al., 1990; Shen Xiangie et al., 1992; Stocklin, 1983; Tapponnier et al., 1986; Teng Jiwen, 1985; Research Group of the CIT, Harvard Univ. and MIT, 1987; Regional Geology of Tibet, 1993; State Seismological Bureau, 1992). Space limitations prevent all of the diverse models that have been proposed to be pre- sented one by one. Many factors have contributed to the thickening, shortening and uplift of the QTP and among these, the following should be taken into consideration in the model:

1 Tectonic deformation is the main factor. Geophysical data obtained in the last ten years reveal that the QTP, and may be divided into three structural layers. The first layer, considered as the upper crust, extends to 10 to $30 \mathrm{~km}$. Brittle and ductile deformation are dominant in this layer. A low-velocity/lowresistivity layer at the base of the first layer (Xiao Xuchang et al., 1988) acts as a decoupling level along which listric thrusting caused crustal thickening, shortening, and uplift of the plateau. The second structural layer, regarded as the lower crust, is between the low-velocity/low-resistivity layer and a depth of $50 \cdots 60 \mathrm{~km}$. Here the crustal thickening and shortening was induced mainly by ductile and plastic deformation. The third structural layer is at a depth of $50 \sim 60$ to $70 \sim 80 \mathrm{~km}$, and is characterized by anomalous mantle or crust-mantle mixtures due to the upwelling of mantle materials and their interaction with the crust. This layer is dominated by plastic deformation which caused the crustal thickening and shortening.

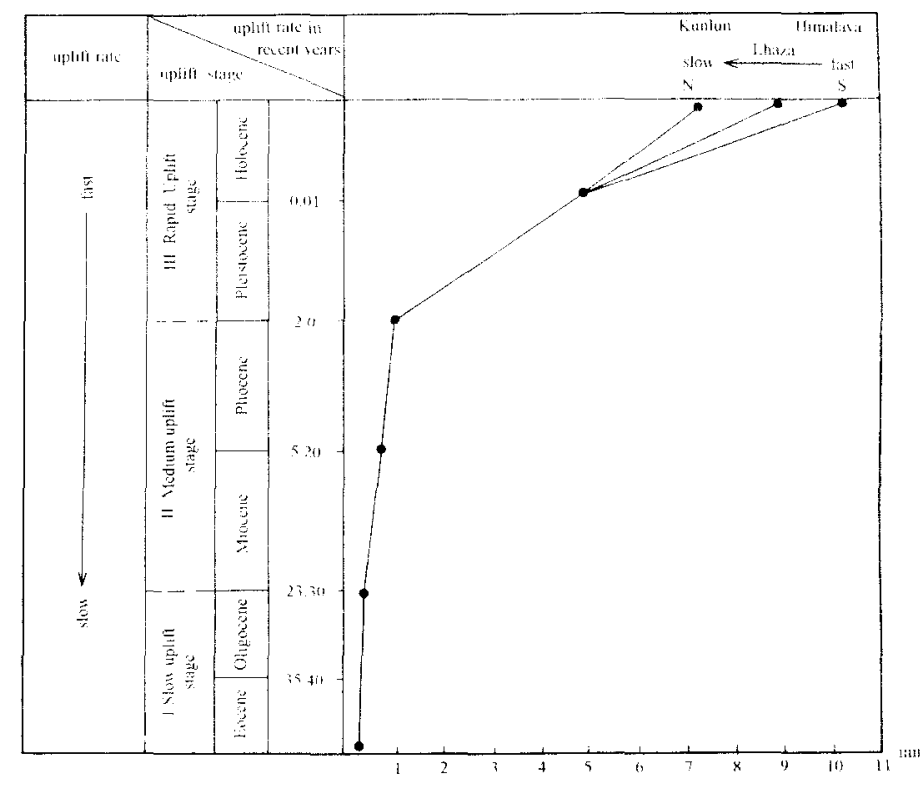

Figure 2 Diagram showing the uplift rates of the Qinghai-Tibet plateau during the Tertiary. 
Heat flow, hydrothermal activity and melting are the important factors which cannot be neglected when considering the tectonic history of the QTP:

- Heat flow of about $71 \mathrm{~mW} / \mathrm{m}^{2}$ has been measured to the south of the QTP in Katmandu, Nepal, and to the north of this, in the Qaidam basin it is about $70 \mathrm{~mW} / \mathrm{m}^{2}$. In the plateau proper however the heat flow increases to $92 \sim 146 \mathrm{~mW} / \mathrm{m}^{2}$ (Shen Xiangie et al., 1992)

- Very low $Q$ values prevale in the QTP. $Q_{\beta}$ is $65 \sim 100$ at a depth of $13 \sim 33 \mathrm{~km}$ in the upper crust and $18 \sim 110$ at $55 \mathrm{~km}$ in the lower crust. These values are most probably consistent with the upper and lower low-velocity layers respectively (Teng Jiwen, 1985).

- Long-period seismic records show that the Lg phase is weak or missing in the QTP.

- The results of tomographic studies show that a swell (plume?) exists at depth, reaching the core-mantle boundary beneath the QTP. This also suggests that the heat flow energy is from a very deep layer (Research Group of the CIT, Harvard Univ. and MIT, 1987).

The deep geophysical data, the heat flow, the seismic velocity data, the very low $Q$ values, the missing $L g$ wave and the seismic tomography seem to indicate that there is a low-viscosity, highly molten layer with intense geothermal activity in the deeper part of the QTP. The thickening, shortening and uplifting of the QTP were probably brought about by heat expansion. Isostatic adjustment is one of the major factors in the last stage of uplift of the QTP. Since the Tertiary, lithosphere downwarping inevitably has ocurred due to the static load pressure resulting from the thickening of the crust. So the QTP was in the state of isostatic compensation. Later, in the Pleistocene to Holocene, the compressive force from the Indian terrane decreased, leading to upwarp of the previously downwarped area.

Rapid uplift and high positive gravity isostatic anomalies $\left(60 \sim 80310^{-5} \mathrm{~m} / \mathrm{s}^{2}\right)$ occurring in the Himalaya region since the Tertiary (Meng Lingshun, 1992) are due to intensive compressive stress and strong deformation events such as the thrusting, over-faulting and overlapping. These affected both the lithosphere and upper mantle and resulted in the upper mantle being squeezed upwards. To the north of the Himalaya region, the compressive stress was released and isostatic adjustment led to the uplifting of the Tibet plateau.

\section{Conclusions}

Multidisciplinary studies indicate that during the late Palaeozoic to early Mesozoic, most of Tethys was an epeiric sea, not a vast deep ocean. The presence of ophiolites and ophiolitic melanges along the Yarlung-Tsangpo (YTSZ), Lancang-Bangong (LBSZ) and Jinshajiang (JSZ) suture zones fully demonstrate that a narrow deep trough or a small oceanic basin, was formed by rifting.

The causes of the rise of the Qinghai-Tibet plateau are complicated, involving many factors. Our preliminary synthesis indicates that early-stage compression by the India terrane; thermal effects and expansion; and a late-stage (Pliocene to Holocene) isostatic adjustment are the three major factors leading to the rise of the plateau.

\section{Acknowledgments}

The authors deeply thank Professors J Y Chen, S Chatteree, Li Tingdong, Lin Jinlu, Meng Lingshun, A B Smith, Shen Xianjie, Wen Shizuan, D R Watts, Xu Juntao, and Yang Jingsu as well as others for providing papers concerning the tectonic evolution and the rise of the Qinghai-Tibet plateau.

\section{References}

Ahmad, F, 1978, Gondwanaland, the concept that failed: Birbal Sahni, Institute of Palacobotany, Lucknow, pp.1-26

Burchfiel, C, et al., 1992. The south Tibetan detachment system. Himalayan Orogen: Geological Society of America. Special Paper 269,41pp.

Carey, S W, 1976, The Expanding Earth: Elsevier, Amsterdam, pp. $366-488$.

Chatterjee, S, 1987, A new tetrapod dinosaur from India with remarks on the Gondwana-Laurasia connection in the Late Triassic: Proceedings of Conference Gondwana 6: Stratigraphy: Sedimentology and Palaeontology. pp. 183-190.

Chen, J A Y et al., 1994, Crustal movement and gravity field of the Mt Qomolangma (Everest) and its adjacent area: Chinese Science Bulletin, v. 39, no. 13, pp. 1204-1207.

Dewey, J F, Shackleton, R M, Chang Chengfa and Sun Yiyin, 1990, The tec tonic evolution of the Tibet plateau, in The geological evolution of Tibet The Royal Society, London, pp. 379-408.

Dietz R S, and Holden J C, 1970. The breaking up of Pangaea: Scientific American, 223(4), pp.30-41.

Dong Xucbin et al., 1990, New palaeomagnetic results from Yadong-Gol mud geoscience transect and a preliminary study on the model of terranes evolution in Qinghai-Tibet plateau: Bulletin of the CAGS, no. 21 pp.39-148.

Harrison, T M, et al., 1992, Raising Tibct: Science, v. 225, pp.1663-1669.

Kaila, K L, et al, 1978, Structure of Kashmir-Himalayas from deep seismic soundings: Journal of the Geological Society of India, v. 19, pp.I-20.

Kidd, W S F, and Molnarp, 1990, Quaternary and active faulting observed on the 1985 Academica Sinica-Royal Society Geotraverse of Tibet, in Report of the Royal Society-Academic Sinica Geotraverse of Qinghai Tibet Plateau, pp.348-371.

Klootwijk, C T et a1., 1992, An early India Asia contact, Palaeomagnetic constraints from Ninetyeast Ridge, ODP Leg 121: Geology, v. 20, pp.395-398.

Li Tingdong, 1988, Deep structure and uplift mechanism of the QinghajTibet plateau: Geological Memoir, Ministry of Gcology and Mineral. Resources, China, ser. 5, no. 7, pp.174-185.

I. in Jinlu and Watts, D R, 1990, Palaeomagnetic results from the Tibetan Plateau, in Report of the Royal Society-Academic Sinica Geolraverse of Qinghai-Tibet Plateau, pp.239-262.

Liu Xun et al., 1992, The stratigraphy, palaeobiogeography and sedimentarytectonic evolution of Qinghai-Tibet plateau: Geological Memoir. Ministry of Geology and Miner. Resources, China, ser. 2, no. 15, 169pp.

Meng Lingshun, 1992, Gravity survey and the lithosphere structure in Qing hai-Tibet plateau: Geological Memoir, Ministry of Geology and Mineral Resources, China ser. 5, no. 13,11.3pp.

Molnar. Pet al., 1987a, Geomorphic evidence for active faulting in the Altyn Tagh and $N$. Tibet and qualitative estimates of its contribution to the convergence of India and Eurasia: Geology, 15, pp.249-253.

Mo Xuanxue, 1992, New facts and concepts on the volcanism and volcanic rocks in the orogenic belts in W. China: Contributions to Petrology, no. $11, \mathrm{pp} .47-55$.

Patriat P et al., 1984, India-Eurasia collision chronology has implications for crustal shortening and driving mechanism of plates: Nature, v. 311, pp.615-621.

Pan Guitang et al., 1990, Cenozoic tectonic evolution of Qinghai-Tibet Plateau: Geological Memoir, Ministry of Geology and Mineral Resources, China, ser. 5, no. 9, pp.141-152.

Qureshy M N, 1974, Vertical tectonics in middle Himalayas, an appraisal from recent gravity data: Bulletin, Geological Society of America, 85, pp. $201-230$.

Research Group of the CIT Harvard Univ. and MIT, 1987, Science and the citizen: Scientific American, v. 256, no. 2, pp.42-44.

Shen Xiangjic et at., 1992, Heat flow and tectonic thermal evolution of terranes of the Qinghai-Tibet Plateau: Geological Memoir, Ministry of Geology and Mineral Resources, China, ser. 5, no. 14, 94pp.

Smith A B and Xu Juntao, 1990, Palaeonotology of the 1985 Tibet geotransverse, Lhasa to Golmud, in Report of the Royal Society-Academic Sinica Geotraverse of Qinghai-Tibet Plateau, pp.49-106.

State Seismological Bureau (SSB), 1992, The active Altyn Fault, 314pp.

Stocklin J, 1983, Himalayan orogeny and Earth expansion: Expanding Earth Symposium, Sydney, pp. 119-130.

Sun Ailing, et al., 1992, The Chinese fossil reptiles and their kins: Science Press, Beijing, New York, p.231.

Tapponnier et al., 1986, On the mechanics of the collision between India and Asia, in Collision Tectonics: Geological Socicty of London Special Publication, 19, pp.115-157. 
Teng Jiwen, 1985, An introduction to geophysical study on the Tibetan Plateau area: Acta. Geophysica Sinica, v. 28, supplement 1, pp.1-5.

Wegener A, 1924, The origin of Continents and Oceans: Methuen and Co. Ltd., London, 219pp.

Wen Shixuan, 1992, New palaeontological evidence for continental drift in the Qinghai-Tibet plateau: Proceeding of the 1st Symposium on the Tibet Plateau, pp.308-315.

Wu Gongiian, Cui Junwen and Gao Rui et al., 1990, An introduction to the Yadong-Golmud Geo-Transect in Qinghai-Tibet plateau: Bulletin of CAGS, no. 21, pp.1-9.

Xia Daixiang et al., 1993, Regional geology of Tibet (Xizang): Geological Memoir Ministry of Geology and Mineral Resources, China, ser. 1, no. $31,707 \mathrm{pp}$.

Tingdong $\mathrm{Li}$, Academician of the Chinese Academy of Sciences (Academic Sinica), is Chief of the Scientific Advisory Group, Chinese Academy of Geological Sciences (CAGS) and now a co-leader of the project Tectonic Evolution and Uplift of the Qinghai-Tibet Plateau. His main research is on regional geology and tectonics. Currently he is in charge of the compilation of a series of geological maps of China and adjacent areas.

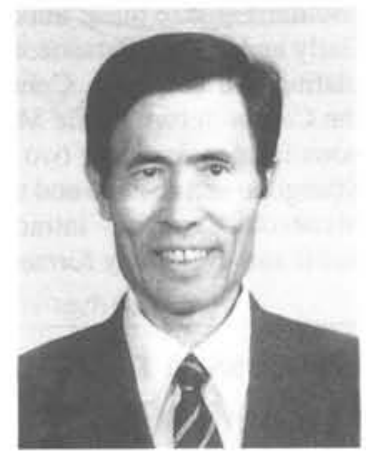

Xuchang Xiao, Academician of the Chinese Academy of Sciences (Academia Sinica), is Chief of the Geoscientific Commission, Institute of Geology, CAGS. He is now responsible for the project Tectonic Evolution and Uplift of the QinghaiTibet Plateau and has investigated tectonics; ophiolites, and highpressure, low-temperature metamorphic rocks in western China for many years.

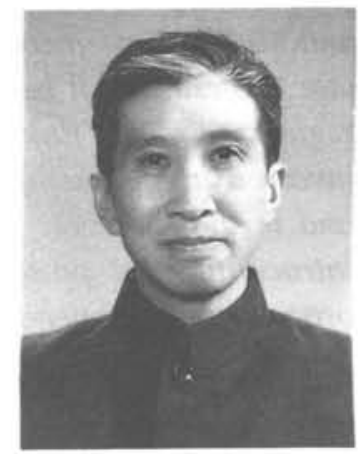

